\title{
ANALISA PEMINJAMAN BUKU PERPUSTAKAAN DENGAN MENGGUNAKAN SISTEM RFID PADA PERGURUAN TINGGI RAHARJA
}

\author{
Untung Rahardja ${ }^{1}$ \\ Yessi Frecilia ${ }^{2}$ \\ Nurul Komaeni ${ }^{3}$ \\ Alumni Universitas Indonesia Program Studi Magister Teknologi Informasi ${ }^{1}$, Alumni STMIK Raharja \\ jurusan Teknik Informatika ${ }^{2}$, Mahasiswa STMIK Raharja Jurusan Sistem Komputer ${ }^{3}$ \\ email:untung@raharja.info,yessi.frecilia@raharja.info,nurul@raharja.info
}

Diterima : 17 Desember 2014/ Disetujui : 14 Januari 2015

\begin{abstract}
Advantages of a technology requires the media to support the process of understanding. Methods that can be used to store or receive data remotely by usinga tool called RFID tags or transponders. One methodthat can be used by officers of the library is still in a process of semi-computer to the process of borrowingbooks in the library. Though the process already usethe technology is there, but officers still commit twicethe work. The constraints of the process due to still use big book for data pribadi will borrow books raharja, who later data will be transferred to a computer by using micsrosoft excel. To overcome the various problems as described above, can be done by usingadditional technology to support the activities of the loaning library using RFID. Then needed a quick and efficient process to resolve problems that occur above. The current process of borrowing and pemindahan data are still semi-computer.
\end{abstract}

Keywords: RFID, Library, iLearning

\section{ABSTRAK}

Keunggulan suatu teknologi memerlukan media yang menunjang proses pemahaman. Metode yang bisa digunakan untuk menyimpan atau menerima data secara jarak jauh dengan menggunakan suatu piranti yang bernama RFID tag atau transponder. Salah satu metode yang dapat digunakan oleh petugas perpustakaan masih menggunakan proses yang semi-komputer untuk proses peminjaman buku pada perpustakaan. Meskipun proses tersebut sudah mengguanakan teknologi yang ada, tetapi petugas masih melalukan 2 kali pekerjaan. Yang menjadi kendala proses dikarenakan masih menggunakan buku besar untuk data pribadi raharja yang akan meminjam buku, yang nantinya data tersebut akan dipindahkan ke komputer dengan menggunakan micsrosoft excel. Untuk mengatasi berbagai masalah seperti yang dijelaskan diatas, dapat dilakukan dengan cara menggunakan teknologi tambahan untuk menunjang kegiatan peminjaman perpustakaan dengan menggunakan RFID. Maka diperlukan proses yang cepat dan efisien agar dapat menyelesaikan masalah yang terjadi diatas. Saat ini proses peminjaman dan pemindahan data masih semi-komputer.

Kata kunci: RFID, Perpustakaan, iLearning

\section{PENDAHULUAN}

Di era yang semakin canggih ini memungkinkan banyaknya akses untuk mencari suatu informasi dengan mudah, salah satunya melalui perpustakaan. Dengan adanya perpustakaan yang ada di
Perguruan Tinggi Raharja, dapat mencari, mengolah ataupun menyimpan data yang kini telah berkembang dengan menggunakan media digital. Teknologi informasi RFID telah membawa perubahan yang cukup signifikan untuk perkembangan pada perpustakaan. 
Perubahan yang sangat penting dan mendasar untuk perkembangan teknologi yang semakin canggih setiap tahun nya.Teknologi informasi dapat digunakan sebagai alat peningkatan kualitas dan produktivitas bagi civitas Perguruan Tinggi Raharja.Teknologi RFID lebih banyak dikembangkan dan dimanfaatkan di berbagai bidang.

Perkembangan perpustakaan yang menggunakan sistem RFID bagi pengelola perpustakaan, dapat membantu pengelola perpustakaan, dapat menyimpan data buku yang ada di perpustakaan agar mudah untuk dicari. Dan dapat juga mengetahui buku apa saja yang sedang dipinjamkan dan belum dikembalikan dengan menggunakan sebuah web based dan database yang berisi data kumpulan buku yang berguna untuk mengetahui buku apa saja yang tersimpan di perpustakaan.

\section{RFID atau Radio Frequency} Identification merupakan suatu metode yang mana bisa digunakan untuk menyimpan atau menerima data secara jarak jauh dengan menggunakan suatu piranti yang bernama RFID tag atau transponder. Suatu RFID tag adalah sebuah benda kecil, misalnya berupa stiker adesif, dan dapat ditempelkan pada suatu barang atau produk.RFID tag berisi antena yang memungkinkan mereka untuk menerima dan merespons terhadap suatu query yang dipancarkan oleh suatu RFID transceiver.

Suatu sistem RFID dapat terdiri dari beberapa komponen, seperti tag, tag reader, tag programming station, circulation reader, sorting equipment dan tongkat inventory tag. Kegunaan dari sistem RFID ini adalah untuk mengirimkan data dari piranti portable, yang dinamakan $t a g$, dan kemudian dibaca oleh RFID reader dan kemudian diproses oleh aplikasi komputer yang membutuhkan nya. Data yang dipancarkan dan dikirimkan tadi bisa berisi beragam informasi, seperti ID informasi lokasi atau informasi lainnya seperti harga, warna, tanggal pembelian dan lain sebagainya. Penggunaan RFID untuk maksud tracking pertama kali digunakan sekitar tahun 1980 an. RFID dengan cepat mendapat perhatian karena kemampuannya dalam men-tracking atau melacak object yang bergerak. Seiring dengan perkembangan teknologi, maka teknologi RFID sendiri pun juga berkembang sehingga nantinya penggunaan RFID bisa digunakan untuk kehidupan sehari-hari.

\section{PERMASALAHAN}

Penanganan yang masih manual dengan peminjaman, masih menggunakan buku besar yang nantinya akan di tanda tangan oleh peminjam buku, yang kemudian dinput dengan komputer yang masih menggunakan microsoft excel sebagai tempat penyimpanan data-data Pribadi Raharja yang meminjam. Petugas melakukan 2x pengerjaan.Maka dari itu diperlukan sistem yang tepat untuk perpustakaan dengan menggunakan teknologi yang harus dirubah, tidak ada lagi secara manual untuk penginputan data.

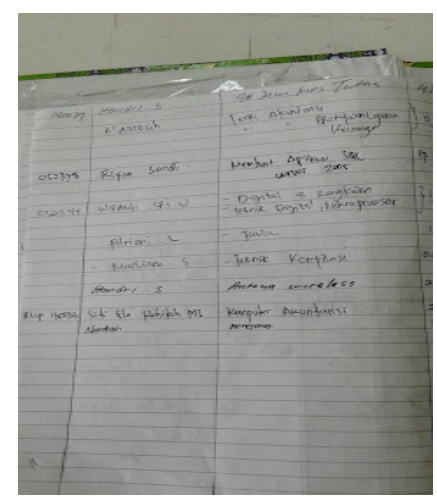

Gambar 1. Masih menggunakan buku besar.

Dengan buku besar sama saja akan menghabiskan kertas yang banyak dengan data yang banyak dan akan menumpuk nantinya, oleh karena itu, kita memperbaharui sistem menggunakan web based dengan terintegrasi dengan RFID untuk mengurangi pemakaian kertas untuk 
menjunjung go green dan data yang tersimpan pun lebih terjamin kerapihannya karena bersifat web based yang tidak akan menghabiskan tempat untuk menyimpannya dan data pun tersimpan dengan aman.

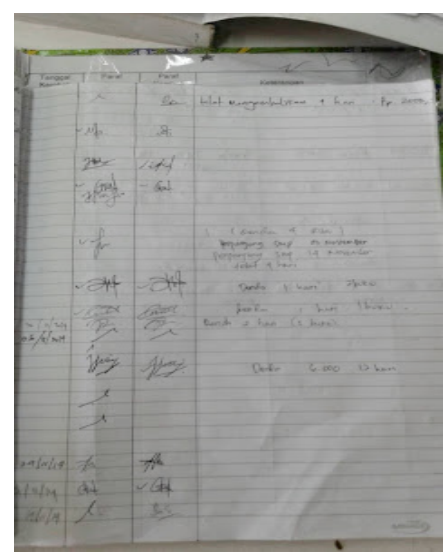

Gambar 2. Menunjukkan Tanda tangan peminjam.

Disini aktivitas peminjam buku perpustakaan dilakukan dengan menggunakan tanda tangan, yang nantinya akan di rekap atau di input ke dalam microsoft excel perpustakaan. Aktivitas ini bisa dibilang kerja dua kali karena setelah customer menulis tanggal serta menandatangani untuk syarat peminjaman kemudian petugas perpustakaan merekap data itu kembali dan memasukkan data tersebut ke dalammicrosoft excel perpustakaan.

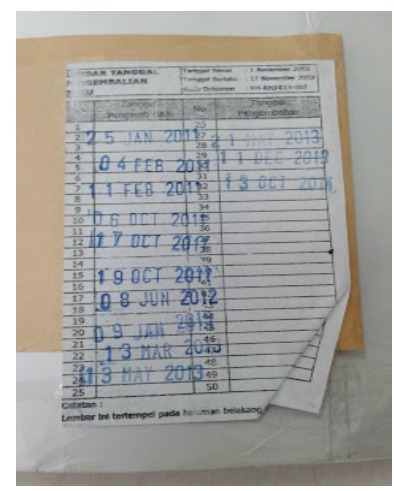

Gambar 3. Aktivitas untuk peminjam buku.

Pada kartu yang telah disisipkan pada bagian buku perpustakaan, terlihat aktivitas peminjaman dengan berupa cap tanggal peminjaman buku yang bertujuan sebagai pembuktian.

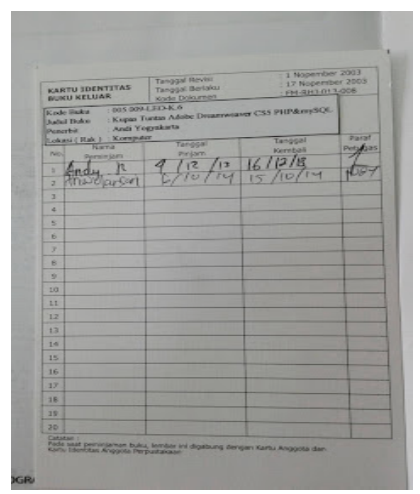

Gambar 4. Data yang diperuntukkan untuk perpustakaan.

Terdapat satu masalah yang menjadi perhatian dalam mengkaji penerapan teknologi RFID. Permasalahan - permasalahan tersebut telah memperlambat proses penerapan RFID. Beberapa diantaranya ialah standarisasi, kebutuhan middleware yang efisien untuk integrasi data, dan privasi. Dalam pembuatan jurnal, ada satu permasalahan yang akan dibahas terbatas pada

1. Apakah RFID dapat membantu peminjaman buku pada perpustakaan agar lebih mudah dan modern?

\section{LANDASAN TEORI}

\section{- Definisi RFID}

Menurut (Maryono, dalam Jurnal Mulawarman 2010), RFID (Radio Frequency Identification) adalah sebuah metode identifikasi dengan menggunakan sarana yang disebut label RFIDatau transponder (tag) untuk menyimpan dan mengambil data jarak jauh. Label atau transponder (tag) adalah sebuah benda yang bisa dipasang atau dimasukkan di dalam sebuah produk, hewan atau bahkan manusia dengan tujuan untuk identifikasi menggunakan gelombang radio. Label RFID 
terdiri atas mikrochip silikon dan antena. Teknologi RFID bergantung pada transmisi data nirkabel melalui medan elektro magnetik. Jantung teknologi ini adalah perangkat yang dinamakan RFID tag. RFID tag adalah sebuah label identifikasi berisi chip yang dapat diprogram, dilengkapi dengan sebuah antena mini. RFID tag bisa dibaca dengan sebuah reader yang dikendalikan komputer tanpa harus membutuhkan direct line-of-sight seperti halnya pembaca barcode. Jangkauan reader ini bisa mencapai satu meter. Supaya informasi yang tersimpan di chip bisa dibaca, reader memancarkan medan frekuensi elektro magnetik yang diterima oleh antena mini di RFID tag. Melalui hubungan elektronis ini, data yang tersimpan bisa dibaca, diproses dan diedit. Tenaga chip terintegrasi ini dipasok melalui medan frekuensi radio yang dipancarkan oleh reader, sehingga RFID tidak membutuhkan sumber tenaga yang terpisah.

\section{- Definisi Website}

Menurut Arief (2011:8), ditinjau dari aspek content atau isi, web dapat dibagi menjadi 2 jenis, yaitu: web statis dan web dinamis. Selain dari sisi content atau isi, web statis dan web dinamis dapat dilihat dari aspek teknologi yang digunakan untuk membuat jenis web tersebut. Adapun jenis-jenis web: Web statis adalah web yang isinya atau content tidak berubah-ubah. Maksudnya adalah isi dari dokumen web tersebut tidak dapat diubah secara cepat dan mudah. Ini karena teknologi yang digunakan untuk membuat dokumen web ini tidakmemungkinkan dilakukan perubahan isi atau data. Teknologi yang digunakan untuk web statis adalah jenis client side scripting seperti HTML, Cascading Style Sheet (CSS). Perubahan isi atau data halaman web statis hanya dapat dilakukan dengan cara mengubah langsung isinya pada file mentah web tersebut. Web dinamis adalah jenis web yang content atau isinya dapat berubahubah setiap saat. Web yang banyak menampilkan animasi flash belum tentu termasuk web dinamis karena dinamis atau berubah-ubah isinya tidak sama dengan animasi. Untuk melakukan perubahan data, user cukup mengubahnya langsung secara online di internet melalui halaman control panel atau administrasi yang biasanya telah disediakan untuk user administrator sepanjang user tersebut memiliki hak akses yang sesuai.

\section{- Definisi Perpustakaan}

Perpustakaan Secara tradisional arti dari perpustakaan adalah sebuah koleksi buku dan majalah. Walaupun dapat juga diartikan sebagai koleksi pribadi perseorangan namun lebih umum dikenal sebagai sebuah koleksi besar yang dibiayai dan dioperasikan oleh sebuah kota atau institusi yang dimanfaatkan oleh masyarakat yang rata-rata tidak mampu membeli sekian banyak buku atas biaya sendiri. (Soeatminah, dalam Jurnal Sutarman 2010).

\section{LITERATURE REVIEW}

Banyak dari literature review yang telah membahas tentang penggunaan RFID untuk perpustakaan yang berguna pada dunia pendidikan saat ini. Dengan memanfaatkan teknologi yang terus berkembang saat ini untuk mengeksplorasi pendidikan. Sebagai landasan teori 
diperlukan studi pustaka untuk memperkuat hasil penelitian dan membandingkan tingkat keberhasilan dari penelitian yang telah dibuat. Beberapa literature review tersebut diantaranya adalah sebagai berikut:

1. Penelitian ini dilakukan oleh Muhammad Jevi Rian Aipasha dan Tri Wahyu Hari Murtiningsih yang berjudul "Efektifitas Radio Frequency Identification (RFID) Di Kelompok Layanan Terbuka Perpustakaan Nasional Republik Indonesia". Penelitian ini dilatar belakangi oleh belum adanya pengukuran dan evaluasi tentang efektifitas RFID dalam proses sirkulasi. Baik efektifitas dalam penggunaan teknologi selfcheck untuk membantu proses peminjaman dan penggunaan teknologi book-drop untuk membantu proses pengembalian koleksi di kelompok layanan terbuka Perpustakaan Nasional RI yang berlokasi di Jalan Medan Merdeka Selatan No. 11 Jakarta Pusat. Dengan tujuan agar mengetahui tingkat efektifitas dan bahan evaluasi untuk melahirkan teknologi yang baru berbasis RFID. Penelitian ini menggunakan metode pendekatan kuantitatif. Populasi dalam penelitian ini adalah pemustaka kelompok layanan terbuka Perpustakaan Nasional RI, dengan jumlah sampel 46 responden dan 6 informan. Metode pengumpulan data menggunakan kuesioner dilengkapi wawancara. Teknik pengolahan data dan analisis kuantitatif menggunakan presentase dan tabulasi hasil kuesioner. Dari hasil penelitian dapat ditarik simpulan bahwa tingkat efektifitas radio frequency identification (RFID) rendah. Masih banyak responden yang menjawab pernyataan tidak setuju. Dengan perhitungan presentase $(\mathrm{P}=\mathrm{f} / \mathrm{n}$ x 100) untuk aspek kecepatan dalam proses peminjaman dengan teknologi selfcheck, pernyataan tidak setuju berjumlah 51,74\%. Dan untuk aspek kecepatan dan fleksibilitas dalam proses pengembalian dengan teknologi book-drop, pernyataan tidak setuju berjumlah 46,09\%. Masih banyaknya pemustaka yang melakukan peminjaman dan pengembalian melalui meja sirkulasi karena kurangnya pengetahuan tentang cara mengoperasionalkan teknologi self-check dan book-drop dan kurangnya perawatan pada mesin tersebut, sehingga tidak dapat digunakan secara optimal.[1].

2. Penelitian yang dilakukan oleh Untung Rahardja, Hidayati, dan Reny Ardyanti, yang berjudul "Keamanan Batasan Data Menggunakan Metode Write Validation Dalam Distribute Database System". Penelitian ini membahas mengenai perkembangan distributed database. Tujuan diterapkannya sistem informasi berbasis web yaitu agar user dapat mengakses informasi dimanapun dan kapanpun. Namun, semakin bertambahnya data, membuat sistem membutuhkan waktu lama dalam melakukan display data. Untuk menanganinya dibuatlah sebuah buffer display yang biasa disebut dengan istilah Data Mart Query (DMQ). Namun, ternyata Data Mart Query (DMQ) tersebut pun mempunyai kendala yaitu data menjadi tidak update sehingga data yang ditampilkan bukanlah data realtime, sementara data selalu berubah setiap saat diberbagai user dan client. Untuk itu diperlukan sebuah solusi baru melalui metode write validation. Walaupun display 
data bukanlah data update, namun dengan metode ini sistem harus melakukan proses validation terlebih dahulu, sebelum eksekusi dijalankan. Dalam artikel ini, diindentifikasi 2 masalah yang dihadapi dalam suatu sistem terdistribusi khususnya masalah dalam menampilkan view data ke pengguna dengan cepat, namun tetap aman saat dieksekusi, definisi dari write validation, 3 ciri khas write validation, keuntungan dan kelemahan dari write validation, algoritma serta manfaat dari metode ini. Pada implementasinya, ditampilkan listing program yang ditulis menggunakan script ASP. Kontribusi metode write validation dalam distributed database system merupakan suatu solusi yang sangat membantu menjaga keamanan database saat dilakukan eksekusi, walaupun data yang ditampilkan merupakan data buffer yang digunakan demi menjaga standard TWT (Tolerable Wait Time).[2]

3. Penelitian yang dilakukan oleh Doni Saputra, Dedy Cahyadi, dan Awang Harsa Kridalaksana, mengenai Sistem Otomasi Perpustakaan Dengan Menggunakan Radio Frequency Identification (RFID)" Terjadinya perubahan pola pikir tentang perpustakaan, yaitu penyediaan koleksi yang dimiliki ke arah konsep dalam memberikan informasi, telah menjadikan jalinan kerjasama antar perpustakaan dalam menampilkan koleksi yang dapat memudahkan penyampaian informasi, semakin mudah untuk diwujudkan, apalagi dengan adanya perkembangan sistem RFID yang dipakai dalam perpustakaan. Pengembangan perpustakaan yang berbasis RFID bagi tenaga pengelola perpustakaan, dapat membantu pekerjaan di perpustakaan. Pengolahan data dan penyebaran informasi di perpustakaan konvensional sering terjadi hambatan atau masalah, apabila sumber itu masih dalam bentuk kertas yang sifatnya statis atau mengandalkan memori ingatan seseorang sebagai media penyimpanannya, sehingga menimbulkan berbagai permasalahan seperti kehilangan data. Dengan Sistem Otomasi Perpustakaan menggunakan RFID, pengguna sistem dapat melakukan berbagai proses seperti berikut ini : mengatur data pperator; ketentuan denda, mengelola data anggota dan buku, memproses peminjaman buku, pembatalan peminjaman, pengembalian buku, pembatalan pengembalian serta proses pembuatan laporan dan statistik perpustakaan. Dengan Menggunakan RFID pada Perpustakaan Fakultas MIPA Universitas Mulawarman, maka dapat diperoleh kesimpulan, yaitu: teknologi RFID dapat digunakan sebagai pengganti/pelengkap sistem penomoran identifikasi buku dan anggota perpustakaan; dapat dibuat sistem otomasi perpustakaan dalam melakukan pengolahan data perpustakaan seperti otomatisasi identifikasi buku dan anggota perpustakaan dalam proses peminjaman buku, pengelolaan koleksi buku dan keanggotaan perpustakaan. Untuk pengembangan lebih lanjut dapat dibuat dengan menggunakan Tag $R F I D$ yang dapat diprogram (tag aktif) dan dapat melakukan pembacaan dengan jarak yang lebih jauh serta melakukan pembacaan tag secara bersamaan (multiple reading).[3] 
4. Penelitian oleh Rahmad Hidayat Meneliti tentang "Teknologi Wireless RFID Untuk Perpustakaan Polnes : Suatu Peluang “. RFID (Radio Frequency Identification) merupakan proses pengidentifikasian suatu objek secara otomatis dengan frekuensi radio. Ada dua komponen penting dalam sistem RFID yaitu kartu (Tag) dan pembaca (Reader). Pada aplikasinya di perpustakaan, tiaptiap buku yang akan diidentifikasi oleh tag yang bisa dibaca oleh reader. Proses pembacaan dilakukan tanpa kontak langsung. RFID dapat dipergunakan untuk menjalankan dua fungsi sekaligus yaitu identifikasi dan sekuriti. Kemudian dengan kemampuan self-service, $R F I D \quad$ mampu mempercepat layanan sirkulasi peminjaman dan pengembalian buku, meningkatkan pengelolaan koleksi dengan memelihara koleksi pada susunan yang benar (reshelving). Keunggulan RFID lainnya dibanding teknologi barcode adalah adanya tag anti pencurian (anti-thieft detection) serta dukungan layanan self-return books drops. Dengan demikian tool ICT ini akanmemberikan peluang peningkatan kualitas pelayanan serta peluang penghematan biaya operasional perpustakaan. [4]

5. Penelitian yang dilakukan oleh Mardiyono, Idhawati H., Tri Raharjo Yudantoro, Muhammad Muqorrobin mengenai"Rancang Bangun Sistem Pendeteksi Pencurian Buku Perpustakaan Berbasis RFID". Sistem mandiri pada perpustakaan berbasis RFID memerlukan pendeteksian status buku yang keluar dari perpustakaan. Sistem pendeteksi konvensional mempunyai fitur mencatat tag buku yang tercuri sekaligus mengaktifkan alarm. Hal ini belum bisa mengetahui wajah pelaku apabila tindak pencurian dilakukan di luar jam kantor atau ketika tidak ada petugas. Membahas tentang pembangunan sistem pendeteksi pencurian yang dilengkapi dengan perekaman wajah pelaku yang dapat disimpan dalam pangkalan data untuk keperluan analisis dan penyelidikan. Arsitektur sistem terdiri dari beberapa modul meliputi pemroses data tag, pemroses video, dan pangkalan data video. Pengetesan dilakukan dengan melewatkan 1 tag legal dan 1 tag illegal pada reader RFID. Hasil menunjukkan bahwa sistem mampu mendeteksi tag ilegal (buku tercuri) dan memicu sistem alarm dan perekaman video. Penerapan sistem ini akan mencegah terjadinya tindak pencurian dan membantu dalam penyelidikannya.[5]

6. Penelitian yang dilakukan oleh Iwan Kustiawan, Ade Gafar Abdullah, Yuda Muladi mengenai "Rancang Bangun Aplikasi Radio Frequency Identification (RFID) untuk Identifikasi Buku-Buku Perpustakaan di Jurusan Pendidikan Teknik Elektro". Radio Frequency Identification (RFID) melakukan identifikasi otomatis dengan cara menyimpan dan mengirim data secara nirkabel melalui tag RFID atau transponder. Beragam aplikasi mutakhir dari RFID sudah banyak dikembangkan dalam berbagai sektor kehidupan terutama kaitannya dengan identifikasi via gelombang radio baik di bidang otomotif, biomedik, institusi pendidikan, kepolisian, perbankan, laboratorium, dan lain-lain. Tujuan dari penelitian ini adalah 
melakukan rancang bangun aplikasi RFID dalam bidang perpustakaan, sehingga $R F I D$ ini dapat dijadikan solusi alternatif selain barcode sebagai media identifikasi data buku yang tersimpan rapih dalam program basis data melalui dekungan gelombang elektromagnetik. Penelitian dilakukan dengan cara mengidentifikasi buku-buku yang ada di perpustakaan, melakukan perancangan perangkat lunak dan perangkat keras, uji coba sistem, pelaporan, dan publikasi ilmiah. Diharapkan dari hasil pemahaman terhadap salah satu model aplikasi teknologi RFID yang dikaji dalam perkuliahan, adanya keterlibatan mahasiswa dalam proses analisis dan sintesis sistem yang dirancang, juga dapat memberikan kemudahan dalam tata kelola administrasi perpustakaan yang dilakukan di Jurusan Pendidikan Teknik Elektro untuk memperkuat dukungan terhadap point-point akreditasi prodi.[6]

7. Penelitian yang dilakukan oleh Iwan Vanany dan Awaluddin Bin Mohamed Shaharoun mengenai "Pengadopsian Teknologi RFID Di Rumah Sakit Indonesia, Manfaat Dan Hambatannya". Penelitian ini berupaya mengeksplorasi manfaat dan hambatan dari pengadopsian teknologi RFID (Radio Frequency Identification) dalam konteks rumah sakit di Indonesia. Metode investigasi dari penelitian ini menggunakan wawancara dan kuesioner semi-struktur untuk konsultan, peneliti teknologi RFID dan manajer rumah sakit berkatagori besar di Pulau Jawa. Manfaat-manfaat dan hambatanhambatan dari pengadopsian teknologi RFID telah diidentifikasi dari studi literatur. Hambatan dari pengadopsian teknologi RFID dibagi menjadi dua (2) aspek yaitu hambatan dari aspek bisnis dan teknologi. Temuan dari studi ini meyakini bahwa manfaat dari pengadopsian teknologi RFID didominasi oleh sebagian besar responden meyakini bahwa hambatan utama dari pengadopsian teknologi RFID adalah: kompleksnya teknologi RFID, (2) ketiadaan informasi yang lengkap dan valid, (3) tidak tersedianya anggaran yang cukup. Detail dari hasil studi dan implikasinya akan didiskusikan selanjutnya.[7]

Dari tujuh literature review yang ada, telah banyak penelitian mengenai metode penggunaan perpustakaan dengan menggunakan teknologi RFID .Itulah alasan mengapa penulis tertarik untuk membahas hal tersebut.Agar nanti bisa dijadikan acuan sebagai referensi oleh dosen maupun mahasiswa.

\section{PEMECAHAN MASALAH}

Untuk mengidentifikasikan permasalahan yang terjadi di dalam perpustakaan yang dijelaskan diatas, dengan penggunaan teknologi RFID sebagai alat bantu untuk petugas dalam penanganan peminjaman buku pada perpustakaan. Diperlukan proses barcode telah menjadi cara utama untuk pelacakan buku, dan sebagainya.

Teknologi pilihan untuk tracking majalah, buku, tugas akhir, jurnal, makalah perpustakaan, bahkan kendaraan dan pustakawannya.Salah satu alasannya adalah kemampuan baca tulis dari sistem $R F I D$ aktif memungkinkan penggunaan aplikasi interaktif. Selain itu, tag juga dapat baca dari jarak jauh dan mampu melalui bahan seperti asap atau cat di mana barcode telah terbukti tidak dapat 
digunakan secara garis besar sebuah sistem RFID terdiri atas tiga komponen utama, yaitu tag, reader, dan basis data. Secara ringkas, mekanisme kerja yang terjadi dalam sebuah sistem RFID adalah bahwa sebuah reader frekuensi radio melakukan scanning terhadap data yang tersimpan dalam tag, kemudian mengirimkan informasi tersebut ke sebuah basis data yang menyimpan data yang terkandung dalam tag tersebut.

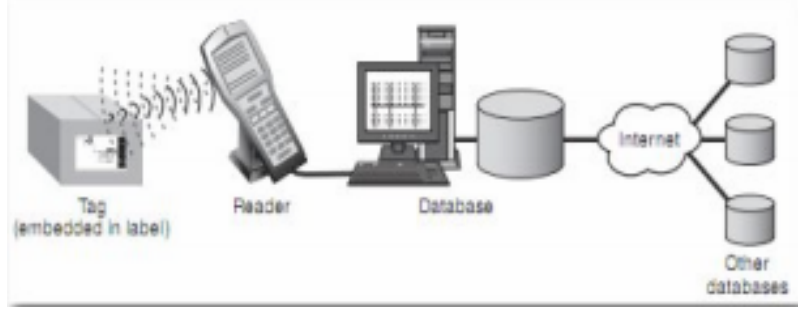
Gambar 5. Komponen Utama Sistem
RFID (Rahmad Hidayat)

Sistem RFID merupakan suatu tipe sistem identifikasi otomatis yang bertujuan untuk memungkinkan data ditransmisikan oleh peralatan portable yang disebut tag, yang dibaca oleh suatu reader RFID dan diproses menurut kebutuhan dari aplikasi tertentu.Data yang ditrasmisikan oleh tag dapat menyediakan informasi identifikasi atau lokasi, atau hal-hal khusus tentang produk-produk ber-tag, seperti harga, warna, tanggal pembelian, dan lainlain.Penggunaan $R F I D$ dalam aplikasiaplikasi pelacakan dan akses pertama kali muncul pada tahun 1980-an. RFID segera mendapat perhatian karena kemampuannya untuk melacak objek bergerak. Seiring semakin canggihnya teknologi, semakin meluas pula penggunaan tag RFID. Sebuah tag RFID atau transponder, terdiri atas sebuah mikro (microchip) dan sebuah antena.Chip mikro itu sendiri dapat berukuran sekecil butiran pasir, seukuran $0,4 \mathrm{~mm}$. Chip tersebut menyimpan nomor seri yang unik atau informasi lainnya tergantung kepada tipe memorinya. Tipe memori itu sendiri dapat read-only, read-write, atau write-once read-many. Antena yang terpasang pada chip mikro mengirimkan informasi dari chip ke reader. Biasanya rentang pembacaan diindikasikan dengan besarnya antena.Antena yang lebih besar mengindikasikan rentang pembacaan yang lebih jauh.Tag tersebut terpasang atau tertanam dalam objek yang akan diidentifikasi. Tag dapat di-scan dengan reader bergerak maupun stasioner menggunakan gelombang radio.

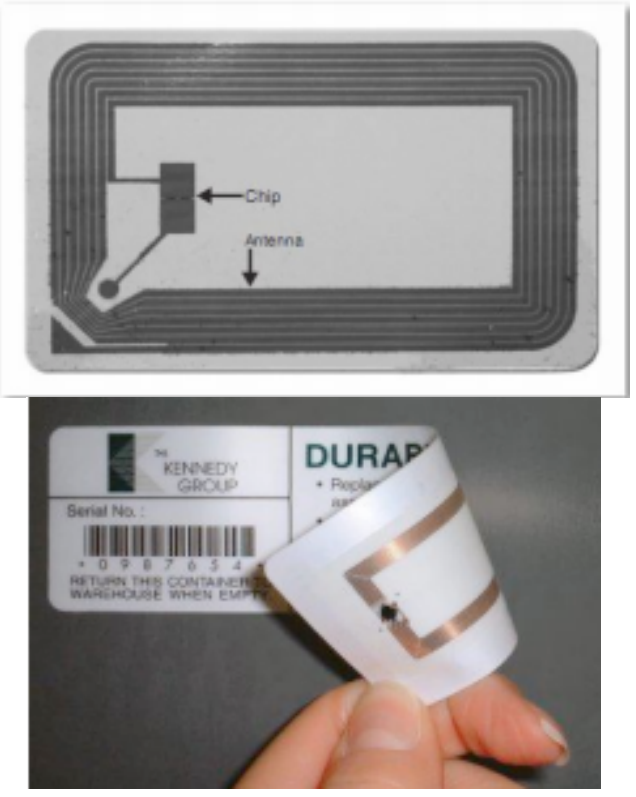

Gambar 6. Tag RFID

Tag RFID sangat bervariasi dalam hal bentuk dan ukuran. Sebagian tag mudah ditandai, misalnya tag antipencurian yang terbuat dari plastik keras yang dipasang pada barang-barang di toko. Tag untuk tracking hewan yang ditanam di bawah kulit berukuran tidak lebih besar dari bagian lancip dari ujung pensil. Bahkan ada tag yang lebih kecil lagi yang telah dikembangkan untuk ditanam di dalam serat kertas uang. Tag versi paling sederhana adalah tag pasif, yaitu tag yang tidak memiliki catu daya sendiri serta tidak dapat menginisiasi komunikasi dengan reader. Sebagai gantinya, tag merespon emisi frekuensi radio dan menurunkan dayanya dari gelombang-gelombang energi yang dipancarkan oleh reader.Sebuah tag pasif minimum mengandung sebuah indentifier unik dari sebuah item yang dipasangi tag tersebut. Data tambahan dimungkinkan untuk 
ditambahkan pada tag, tergantung kepada kapasitas penyimpanannya . Dalam keadaan yang sempurna, sebuah tag dapat dibaca dari jarak sekitar 10 hingga 20 kaki. Tag pasif dapat beroperasi pada frekuensi rendah (low frequency, LF), frekuensi tinggi (high frequency, $H F$ ), frekuensi ultra tinggi (ultrahigh frequency, UHF), atau gelombang mikro(microwave). Contoh aplikasi tag pasif adalah pada sistem angkutan massal (Mass Rapid Transit-MRT), autentikasi masuk gedung dan barang-barang konsumsi .Harga tag pasif lebih murah dibandingkan harga tag versi lainnya.Perkembangan tag murah ini telah menciptakan revolusi dalam pengadopsian $R F I D$ dan memungkinkan penggunaannya dalam skala yang luas baik oleh organisasi-organisasi pemerintah maupun industri.

\section{IMPLEMENTASI}

Tampilan website Perpustakaan RFID Perguruan Tinggi Raharja yang memiliki berbagai macam fitur yang dapat digunakan oleh petugas perpustakaan, mahasiswa maupun dosen yang terdiridari

\section{a. Halaman Utama}

website tersebut dapat diakses diluar kampus oleh mahasiswa maupun dosen dengan menuju alamat website http://rfid-perpusrhj.esy.es/

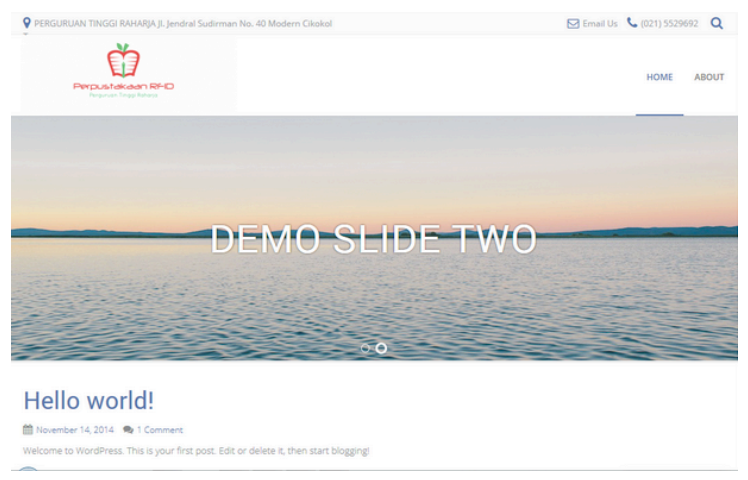

Prototype 1. Tampilan Screen pada Perpustakaan RFID

b. Form Biodata Mahasiswa
Adanya tampilan penginputan form biodata Pribadi Raharja untuk memudahkan petugas perpustakaan dalam merekap siapa saja Pribadi Raharja yang telah meminjam buku pada perpustakaan.

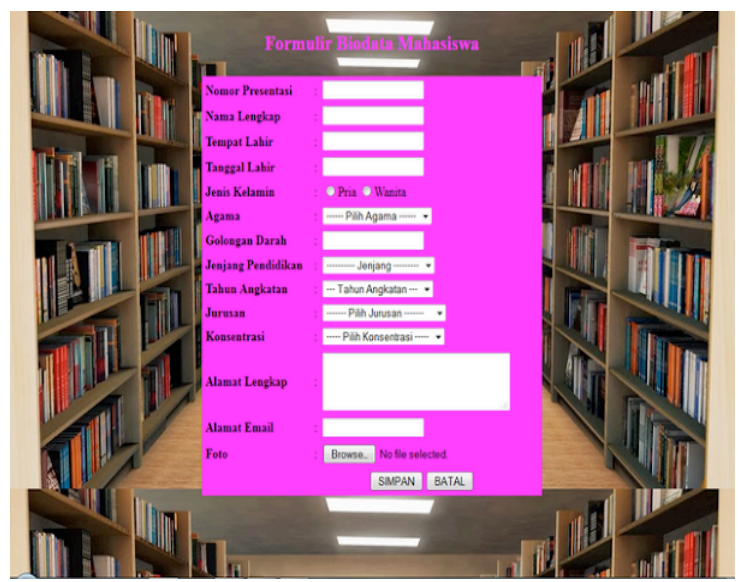

\section{Prototype 2 . Formulir Biodata Pribadi Raharja.}

Tampilan diatas dijalankan dengan source code php yang di hubungkan dengan database mysql menggunakan phpmyadmin sehingga menjadi sebuah program yang berfungsi untuk menjalankan perintah penginputan data.Berikut uraian listing program form biodata Pribadi Raharja.

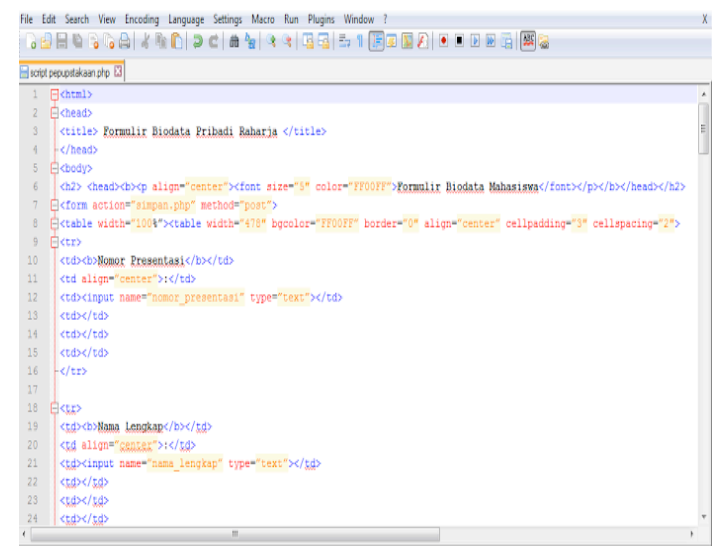

\section{Listing Program 1. Source code Form biodata Mahasiswa}

c. Sub Peminjaman

Untuk proses peminjaman, tidak semua pengunjung perpustakaan dapat melakukan peminjaman buku. Hak peminjaman atas buku dan inventaris perpustakaan diberikan hanya bagi orang-orang yang 
teridentifikasi member oleh sistem. Oleh karena itu, pertama kali, reader akan meminta scan tag member terlebih dahulu sebelum melakukan scan terhadap itemitem yang akan dipinjam.

\section{d. Sub Pengembalian}

Pada jalur pintu masuk disediakan tempat untuk proses pengembalian buku. Dalam hal ini, sistem tidak meminta untuk scan tag ID member. Hanya dengan meletakkan buku pada tempat, reader akan mendeteksi tag buku. Sistem akan mencari data buku tersebut pada basis data peminjaman. Bila tanggal saat buku dikembalikan telah melewati tanggal pengembalian default maka akan terkena denda. Denda dibayarkan pada admin yang sedang berjaga.Flowchart dari sub peminjaman ditunjukkan oleh Gambar 9.

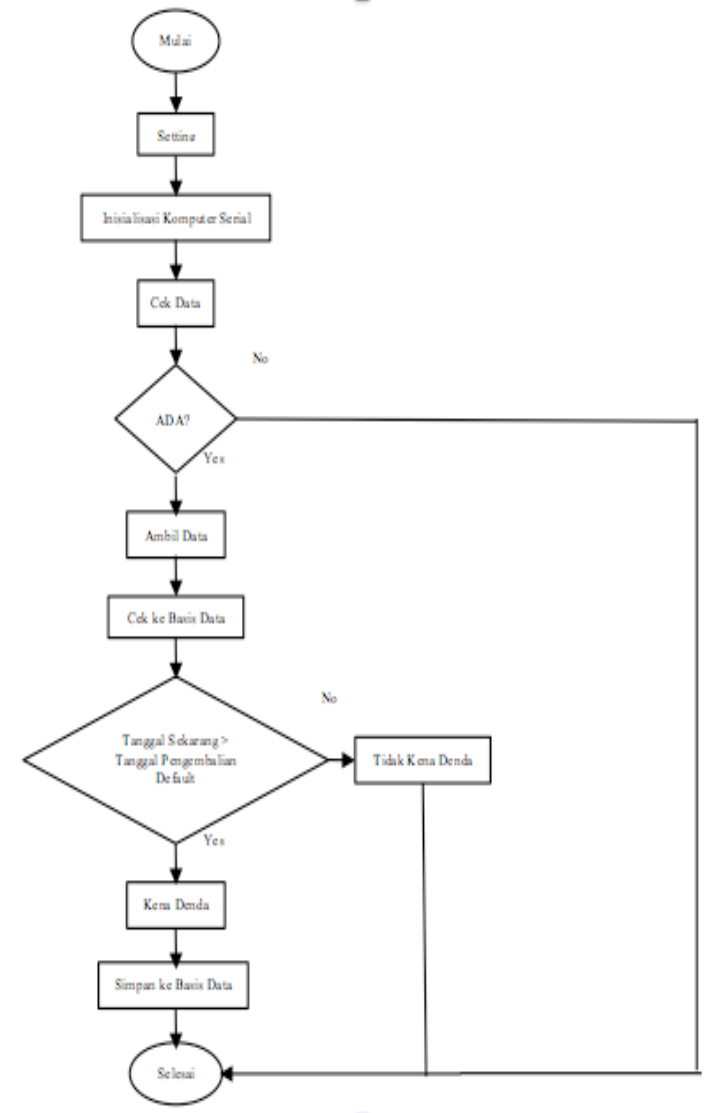

Flowchart 1. Flowchart Sub peminjaman.

e. Sub reader/write RFID

Reader yang digunakan untuk membaca dan menulis suatu data untuk sistem perpustakaan menggunakan RFID Reader $A C R 122 U$.

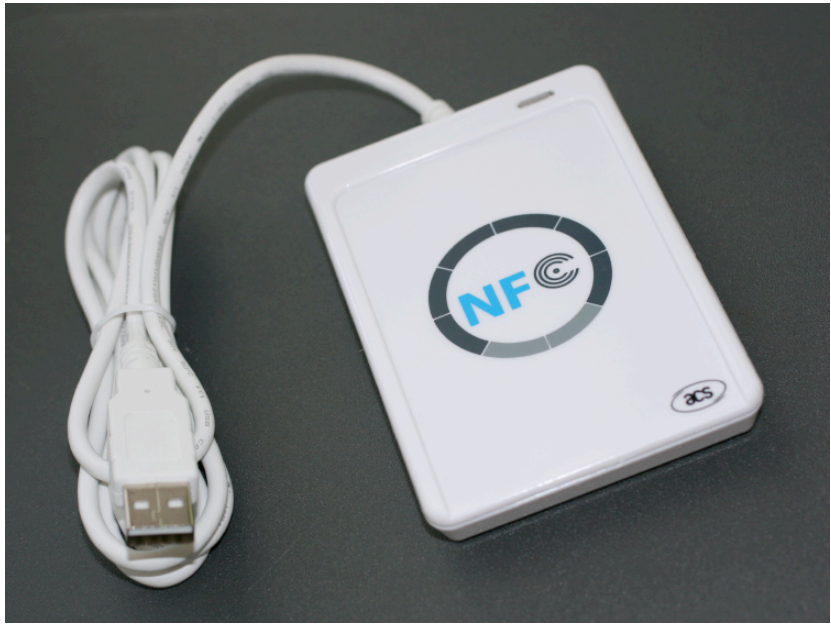

Gambar 9. Reader RFID PCR $122 U$

f. Sub stiker/label RFID

Stiker/label yang digunakan untuk ditempelkan di cover buku agar buku mudah dibaca dan ditulis oleh reader RFID tersebut.

\section{Kelebihan dan Kekurangan RFID pada perpusatakaan}

Diantara 8 (delapan) kelebihan yang dimiliki oleh teknologi $R F I D$, ada 2 (dua) kelebihan perpustakaan dengan menggunakan RFID diantaranya yaitu :

1. Penggunaan RFID mengurangi jumlah waktu yang dibutuhkan untuk melakukan operasi sirkulasi. Penghematan waktu yang paling signifikan yang disebabkan fakta bahwa informasi dapat dibaca dari tag RFID dan beberapa item dalam tumpukan dapat dibaca pada waktu yang sama.

2. Mempunyai fungsi identifikasi dan sekuriti,

3. Membaca data secara otomatis tanpa memperhatikan garis arah pembacaan,

Diantara 8 (delapan) kelemahan yang dimiliki oleh teknologi RFID, ada 2 (dua) kelemahan perpustakaan dengan menggunakan RFID diantaranya :

1. masalah biaya dan 
2. susceptibility of the tag (keringkihan label plastik).

\section{KESIMPULAN}

\begin{abstract}
Dengan demikian dapat disimpulkan bahwa perpustakaan RFID dapat membantu Pribadi Raharja dalam peminjaman buku secara mudah dan modern. Dengan sistem RFID Pribadi Raharja tidak lagi melakukan peminjaman manual dengan buku besar yang akan ditanda-tangani oleh si peminjam buku, kemudian diinput dengan komputer yang masih menggunakan microsoft excel sebagai tempat penyimpanan data-data Pribadi Raharja yang meminjam. Maka dari itu diperlukan sistem yang tepat untuk perpustakaan dengan menggunakan teknologi yang harus dirubah, tidak ada lagi sistem secara manual untuk penginputan data. Karena itu disini dibuatkan suatu sistem pencarian buku melalui ID dari tag RFID yang terhubung dengan suatu komputer yang mempunyai basis data. Serta perlunya sistem informasi pengelola data buku perpustakaan yang dapat mengelola perpustakaan dengan mudah, sistem pengolahan data buku ini nantinya dapat dipergunakan untuk pencarian buku, pengolahan, penyimpanan, melihat kembali, dan merekap informasi - informasi. Oleh karena sistem perpustakaan RFID dapat memudahkan si peminjam dalam melakukan peminjaman buku dan transaksi pun lebih cepat karena tidak lagi menggunakan sistem manual yang harus kerja $2 \mathrm{X}$ saat melakukan peminjaman.
\end{abstract}

\section{DAFTAR PUSTAKA}

[1] Aipasha, Muhammad Jevi Rian.Murtiningsih, Tri Wahyu Hari.(2012, Januari) "Efektifitas Radio Frequency Identification (RFID) Di Kelompok Layanan Terbuka Perpustakaan Nasional Republik Indonesia”.
[2] Rahardja, Untung. Hidayati. Ardyanti, Reny. (2010, Februari) "Keamanan Batasan Data Menggunakan Metode Write Validation Dalam Distribute Database System" [Online]. Tersedia di http://raharja.ac.id/

[3] Saputra, Doni. Cahyadi, Dedy. Kridalaksana, Awang Harsa. (2010, September) "Sistem Otomasi Perpustakaan Dengan Menggunakan Radio Frequency Identification (RFID)".

[4] Hidayat,Rahmad. (2010, Februari) "Teknologi Wireless RFID Untuk Perpustakaan Polnes : Suatu Peluang".

[5] Mardiyono. H, Idhawati. Yudantoro, Tri Raharjo. Muqorrobin, Muhammad Muqorrobin. (2012, April) "Rancang Bangun Sistem Pendeteksi Pencurian Buku Perpustakaan Berbasis RFID". ISSN: 2252-4908.

[6] Kustiawan,Iwan. Abdullah, Ade Gafar. Muladi, Yuda. (2010, Desember) "Rancang Bangun Aplikasi Radio Frequency Identification (RFID) untuk Identifikasi Buku-Buku Perpustakaan di Jurusan Pendidikan Teknik Elektro".

[7] Vanany, Iwan. Shaharoun, Awaluddin Bin Mohamed. (2009, Juni) "Pengadopsian Teknologi RFID Di Rumah Sakit Indonesia, Manfaat Dan Hambatannya". ISSN: 1411-2485 